\title{
Introduktion til en engelsk tradition
}

I de sene 50'ere og i 60'erne har den danske litteraturteori været under stærk indflydelse fra den angelsaksiske verden. Især Johan Fjord Jensens »Den ny kritik $\ll$ og Torben Brostrøms skrifter viderebragte ideer om det autonome værk, og medvirkede til at føre dansk litteraturteori ind $i$ en ahistorisk fase. Dogmet om det litterære værks autonomi slog igennem i en stor del af universitetsundervisningen, ikke blot inden for faget engelsk, men også i danskfaget, og har dermed påvirket mange senere gymnasielæreres litteratursyn. Dette teoretiske perspektiv slog derfor også igennem i gymnasieundervisningen og har været med til at nedbryde den kronologiske, litteraturhistoriske og biografiske tradition fra Vilhelm Andersen.

Denne ahistoriske tilgang til litteraturbeskæftigelsen har utvivlsomt også varet med til at bane vejen for den senere »pragmatiske fase $i$ dansk-faget - og til dels også i fremmedsprogene $i$ gymnasium og HF. En udvikling, som f.eks. kan aflæses i den nye vejledning for undervisningen i gymnasiet fra 1971 og i vejledningen for HF-undervisningen fra 1974.

Den ny kritik, forstået som en litteraturkritisk bevægelse, havde koldkrigsovertoner af anti-materialisme og anti-marxisme. I fremstillinger som f.eks. den indflydelsesrige Daiches' »Critical Approaches to Literature (1956) blev hele den materialistisk orienterede litteraturkritik, som interesserede sig for forholdet mel- 
lem forfatter, værk og samtid, slået sammen i ét og afvist som sovjetisk dogmatik.

Denne litterære koldkrigsholdning er siden blegnet $\mathbf{i}$ takt med den politiske kolde krig og erstattet af en mere udbredt accept af $»$ kontekstanalyser « inden for den engelske litteraturkritik. Det betyder, at der nu eksisterer en bredere vifte af tilgange omfattende forskellige grader af »materialisme $«$, fra litteratursociologi i mere traditionel forstand til fors $\varnothing \mathrm{g}$ på at udvikle »marxistiske « analyser.

Mange af de yngre litteraturkritikere i England er begrebsmæssigt påvirket af fransk strukturalisme (Goldmann og Althusser); men samtidig - og heldigvis - bærer deres analyser måske endnu stærkere præg af påvirkning fra den udviklede, særegne socialhistoriske tradition, som findes i England.

Indføjningen af litterære, kulturelle analyser $i$ denne socialhistoriske tradition har vist sig meget perspektivrig, især for den ældre litteraturs vedkommende. Det er netop den særegne sammensmeltning af socialhistorisk og litterær analyse, der påkalder sig interesse i vores sammenhæng, dvs. i forbindelse med fors $\emptyset$ get på at diskutere og udvikle det historiske perspektiv i danskstudiet og danskfaget i skolen.

Jeg vil derfor først kort introducere denne socialhistoriske tradition (især med E. P. Thompson som eksempel) og dens litteraturhistoriske modstykke (ud fra Raymond Williams). Dernæst vil jeg, ved hjælp af et nyere eksempel hentet fra Terry Eagletons kritiske forfatterskab, prøve at vise, hvorledes denne socialhistoriske tradition kan frugtbargøre den litterære analyse. Og endelig vil jeg kort diskutere, hvorledes disse tendenser kunne anvendes i en dansk sammenhæng.

\section{DEN ENGELSKE SOCIALHISTORISKE TRADITION}

Mange har, uden at tænke nærmere over det, allerede indirekte stiftet bekendtskab med denne socialhistoriske tradition. Det har de gjort ved at lase Jürgen Habermas' »Borgerlig Offentlighet « (1962). Habermas kunne næppe have skrevet sin bog uden at 
trække så kraftigt på denne tradition, som han faktisk gør. Men det er ikke en retfærdig repræsentation, for stoffet er lagt til rette, så det tjener Habermas' egne interesser.

Karakteristisk for traditionen er interessen for historiske udviklingsforklaringer, der samtidig omfatter detaljerede analyser af $\emptyset$ konomiske, klasse- og bevidsthedsmassige forhold. Det er en tradition, der har en lang historie bag sig, og den skal bl.a. forklares ved, at England som bekendt var det første land, der oplevede industrialiseringen og dens følger (allerede fra onkring 1780).

Der opstod allerede tidligt $\mathrm{i}$ forrige århundrede stor national og international interesse for at få beskrevet denne udvikling, såvel i de store træk som $\mathrm{i}$ detaljen. Det vil være en misforståelse at tro, at kun Marx og Engels analyserede udviklingen i denne »Workshop of the World «. Som det fremgår af deres analyser, forelå der allerede da materialer til en samfundsanalyse $\mathrm{i}$ moderne forstand, i form af regerings- og administrationsrapporter, betænkninger og statistikker.

En del af grundlaget for en moderne samfundsvidenskab var hermed til stede, og det blev anvendt af både tilhængere og kritikere af den industrielle kapitalisme - af både positivister og socialister. På tilsvarende vis blev der allerede tidligt udstukket to tendenser, som siden - $\mathbf{i}$ forskellige former - har præget den engelske socialhistoriske tradition: tilhængerne af forbedringstesen og tilhængerne af forarmelsestesen. De første anså udviklingen under selve industrialiseringsprocessen for at have forbedret vilkårene for samfundets lavere lag, for arbejderklassen. De sidste mente, at industrialiseringsprocessen medførte en stadig forringelse af levevilkårene.

Tilhængerne af forarmelsestesen har fra starten interesseret sig for både økonomiske, klassemæssige og bevidsthedsmæssige forhold, for livssituationen som sådan, mens den anden fløj har været mere $\emptyset$ konomisk-kvantitativt orienteret. I begyndelsen af dette århundrede fik debatten et nyt opsving. Den havde bvilet i perioden siden 1860 'erne p.g.a. den relative fremgang $i$ levevilkårene, som fulgte det $\emptyset$ konomiske opsving i disse år. 
I 1920'rne udspillede kontroversen sig bl.a. mellem historikerne J. H. Clapham og J. L. Hammond. Clapham tilsluttede sig forbedringstesen på grundlag af nogle kvantitative reallønsopg $\varnothing$ relser, mens Hammond lagde vægt på den generelle forringelse af levevilkårene og dermed tilsluttede sig forarmelsestesen. I 30'rnes marxistiske miljø i bl.a. Cambridge fik debatten yderligere liv under indflydelse af krisen og arbejdsløsheden, men også på baggrund af den industrielle udvikling i Sovjet. I modsætning til den tyske Frankfurter-skole var diskussionerne i det stilsvarende « engelske miljø udpræget praksisorienterede (omend lige så isolerede internationalt set).

Efter Anden Verdenskrig fortsættes diskussionen, og den forstærkes nu af efterkrigstids- $\emptyset$ konomernes store interesse for at bestemme forudsætningerne for $\emptyset$ konomisk vækst - således som det, på forskellig måde, fremgår af Maurice Dobbs og Joan Robinsons arbejder.

Interessen var endnu engang praktisk betinget. Spørgsmålet om, hvorledes den industrielle udvikling ville forme sig i u-landene, var blevet et væsentligt udgangspunkt. Og igen rettedes blikket tilbage mod den industrielle revolution og dens følger for England. Deane og Cole skriver »British Economic Growth 1688-1959 (1962) og Deane »The First Industrial Revolution« (1965), hvori de på et kvantitativt grundlag endnu engang føjer argumenter til forbedringstesen.

Men i opposition hertil fremstår en ny generation af historikere - E. P. Thompson, E. J. Hobsbawm, Ch. Hill, Asa Briggs - som tilslutter sig forarmelsestesen. De ser det som deres opgave at gøre op med forestillingerne om, at fremgang og tilbageslag for arbejderklassen alene kan måles ved hjælp af reallønsindekser. De $\emptyset$ nsker at gøre rede for de undertryktes historie og dermed også for nederlagenes historie, for de drømme og håb, som var med til at udvikle arbejderklassens kamp mod kapitalismen. I indledningen til E. P. Thompsons kæmpeværk fra 1963, »The Making of the English Working Class«, som dækker perioden 1780-1832, hedder det programmatisk:

»Jeg fors $\varnothing$ ger at befri den fattige hosebinder, maskinstormeren, 
den *forældede « håndvæver, den »utopiske « håndværker (. . .) fra eftertidens uhyrlige nedladenhed. Deres håndværk og traditioner var ganske vist ved at uddø. Deres fjendtlighed over for industrialismen tilbageskuende. Deres fællesskabs-idealer fantasier. Deres oprørssammensværgelser dumdristige. Men det var dem og ikke os, der gennemlevede denne tid med intens social uro. Deres forhåbninger var gyldige set $\mathrm{i}$ forhold til deres egne erfaringer; og hvis de blev ofre for historien, så er de ofre, fordømt under det liv, der var deres og ikke vort. Vort eneste bedømmelseskriterium bør ikke være, om et menneskes handlinger bør retfærdiggøres i lyset af den efterfølgende udvikling. Når alt kommer til alt, så er vi ikke selv nået til slutpunktet for den sociale udvikling. Måske kan vi gennem en indsigt i de tabte mærkesager, som optog menneskene under den industrielle revolution,fă forståelse for sociale onder, som endnu ikke er fjernet. Desuden er størstedelen af verden idag stadigvæk i færd med at gennemleve problemer omkring industrialiseringen og dannelsen af demokratiske institutioner, som på mange måder er analoge med vores egen erfaring under den industrielle revolution. De mærkesager, som blev tabt i England, har endnu mulighed for at blive vundet i Asien og Afrika.\& (s. 13).

Thompsons værk bringer os vidt omkring i perioden: $\emptyset$ konomi og arbejdssituation for forskellige fraktioner inden for arbejderklassen, levevilkår, klassebevidsthed, religion og meget mere. Stofligt er bogen altså meget bred, men perspektivet, det samles $i$, er en klassebevidsthedsanalyse. Dette viser sig ikke blot $i$ interessen for »nederlagenes historie ; også Thompsons opfattelse af begrebet klasse er central for sigtet $i$ hans analyse. Han stiller sig $i$ opposition, både til en klasseopfattelse, hvor begrebet opfattes som en fasttømret struktur eller en kategori, og til en opfattelse, der bygger på den borgerlige sociologis sociale lagdelingsmodeller. For ham er klasse et historisk fænomen, et historisk forhold som altid er legemliggjort $i$ virkelige mennesker og $i$ en virkelig omverden (kontekst).

Klasseerfaring er $\mathbf{i}$ h $\varnothing \mathrm{j}$ grad determineret af de produktionsforhold, som mennesker fødes under - eller indgår ufrivilligt $i \ll$. 
Klassebevidsthed »er den måde, hvorpå disse erfaringer bliver behandlet $\mathrm{i}$ kulturelle udtryk: levendegjort $\mathrm{i}$ traditioner, værdisystemer, ideer og institutionelle former. Hvis erfaringen fremtræder som determineret, så gør klassebevidstheden det ikke. Vi kan se en logik $i$ reaktionerne hos erhvervsgrupper af samme slags, som gennemgår de samme erfaringer, men vi kan ikke udsige nogen lovmæssighed. Klassebevidsthed opstår på samme måde til forskellige tider og på forskellige steder, men aldrig på helt den samme måde«. (s. 10).

I denne opfattelse af klasse og klassebevidsthed ligger således den teoretiske begrundelse for den detaljerede analyse, som er karakteristisk for Thompson.

Kollegaen Hobsbawm har fulgt en tilsvarende linje. I bogen »Bandits « (1969) ${ }^{1}$ skriver han om de undertrykte, individuelle oprørere $\mathrm{i}$ bondesamfund over hele verden, de ædle røvere af Robin Hood-typen, hævnerne og de primitive frihedskæmpere. Han har været den centrale skikkelse blandt »forarmelsesteoretikerne « $\mathbf{i}$ levevilkårsdebatten i efterkrigstiden. I den forbindelse har han gjort op med reallønsindeks-betragtningen og fremhæver slivskvalitet « $\mathrm{i}$ bredere forstand (madvarers kvalitet, forurening, boligforhold etc.) som det centrale $\mathbf{i}$ bedømmelsen af industrialiseringens følger. Han har også fremhævet nødvendigheden af at afbalancere nationalbetragtninger med regionale studier af levevilkår.

Diskussionerne inden for denne del af den engelske socialhistoriske tradition har således altid været præget af en kombination af interessen for de store udviklingslinjer og disses betydning for specielt arbejderklassens levevilkår og bevidsthed. Analyserne har tilstræbt at behandle såvel $\emptyset$ konomiske som klasse- og bevidsthedsmæssige forhold $\mathrm{i}$ et historisk udviklingsperspektiv. Og det er gjort uden at slække på kravet om en fremstillingsform, der var detaljeret, eksempelrig og relativt let tilgængelig. De marxistiske begreber, der anvendes, virker snarere formidlende end tyngende på fremstillingen, fordi de forstås og anvendes som begreber, der må udvikles historisk. Det er dog først efter Anden Verdenskrig, at bestemmelsen af begreberne klasse og klassebevidsthed er fremstået som et egentligt og erkendt videnskabeligt diskussionsemne inden for forarmelsestraditionen. 
Med Thompson, Hobsbawm med flere findes der således idag en gruppe engelske socialhistorikere, som dels anvender et historisk-materialistisk klasse- og klassebevidsthedsbegreb, dels er i stand til at forbinde analyser af generelle udviklingsperspektiver med mere detaljerede analyser - herunder lokalanalyser - af produktionsforhold og klassebevidsthed, og dels beskæftiger sig med historien ud fra et anvendelses- eller praksisperspektiv.

\section{DEN MATERIALISTISKE LITTERATURKRITIK}

Det er især det stærke element af kulturhistoriske og bevidsthedsmæssige analyser, der har betinget, at denne marxistisk orienterede, socialhistoriske tradition også har berøringsflader ud mod dele af den engelske litteraturkritik. I $\emptyset$ vrigt kan det være temmelig svært at holde de to ude fra hinanden, for de omtalte socialhistorikere inddrager gerne skønlitteratur i deres bevidsthedsanalyser.

Hvad der yderligere har bidraget til at gøre forbindelsen tæt imellem dem er, som Perry Anderson har gjort opmærksom på, ${ }^{2}$ at disciplinen « litteratur- eller kulturteori i England indtager samme plads som den »totalanalyse * - altså analysen af samfundstotaliteten - der er sigtepunktet for f.eks. Frankfurterskolen. Men samtidig er det et faktum, at den engelske litteraturkritik (i snævrere forstand) nok $i$ realiteten har færre impulser at give os på området historisk-materialistiske bevidsthedsanalyse, end socialhistorien har.

\section{A. RAYMOND WILLIAMS}

Raymond Williams' forfatterskab er nok det mest markante udtryk for denne sparallelle udvikling«, og samtidig det mest fremtrædende fors $\emptyset \mathrm{g}$ på at udvikle en litteratur- og kulturteori, i efterkrigstidens England. Williams har fra sit forfatterskabs begyndelse været optaget af, som han selv udtrykker det, at bestemme >kultur « som sforholdene mellem elementerne $i$ hele livssituationen $\varangle,{ }^{3}$ set $i$ et historisk perspektiv.

I sin nok hidtil mest kendte bog, $\gg$ Culture and Society (1958), eftersporer han den historiske udvikling $i$ opfattelsen af begrebet 
kultur fra 1780 til 1950. Analysen er bygget op på forestillingen om, at en falles kultur og ideerne om en sådan har været under udvikling siden begyndelsen af forrige århundrede. Williams f $\varnothing 1-$ ger denne udvikling gennem enkeltanalyser af tænkere og forfattere fra $\gg$ den store engelske tradition \& som f.eks. John Stuart Mill og D. H. Lawrence.

Mens socialhistorikere som Thompson og Hobsbawm allerede tidligt fulgte i Marx' og Engels' fodspor og anvendte deres klassebegreb, har Williams haft vanskeligere ved at nå frem til en historisk-materialistisk analyse af det forhold, der optager ham: kultur og samfund. Begreber som klasse og kultur har haft svært ved at fungere sammen i Williams' forfatterskab - også selv om forfatterskabet i retrospektiv kan ses som ét stort fors $\phi g$ på at bearbejde forholdet imellem dem.

Williams' del- og enkeltanalyser har været mere historisk-materialistiske. De har vist hans sans for at afdække klassemæssige betingelser for litterære og kulturelle udtryk, og det er i denne forbindelse, man kan spore påvirkninger fra den socialhistoriske tradition. Men i sine generelle teorier om den kulturelle udvikling har han fremlagt et optimistisk, populistisk udviklingssyn - og har haft tilsvarende vanskeligt ved at få hold på klasseaspektet.

Som allerede antydet har han i sin kulturteori snarere lagt vægt på at vise, hvordan den samfundsmæssige udvikling fører hen imod et mere udbredt demokrati, og hvorledes den st $\varnothing$ rre udbredelse af massekommunikationsmidlerne bringer et st $\varnothing r r e$ fællesskab og en evt. større lighed nærmere. Han formulerer sig dermed i opposition til kulturpessimister som f.eks. T. S. Eliot.

I Culture and Society « gjorde Williams en del ud af at erklære sig som ikke-marxist, men idag står Williams med bogen »Marxism and Literature « (1977) på et langt mere marxistisk inspireret grundlag. Hans udvikling er symptomatisk for den engelske materialistisk orienterede litteraturteori i efterkrigstiden, ikke mindst fordi Williams næsten har været identisk med denne, eller i hvert fald været dens mest fremtrædende repræsentant gennem hele perioden. Williams' forfatterskab og position har groft taget gennemgået tre faser: en radikal, populistisk fase i 50'erne, 
en fase tilknyttet det ny venstre i 60'erne - med en tiltagende radikalisering af synspunkterne - og endelig en marxistisk »rekonstruktionsfase « i 70'erne.

Selv om denne rekonstruktionsfase i England har været meget abstrakt i sin teoretiske orientering (Goldmann, Althusser) - måske som reaktion på den hidtidigt fremherskende, ateoretiske tendens inden for engelsk litteraturkritik - så er den også resulteret i flere heldige konkrete litterære analyser, der søger at sammenkæde den nyvundne marxistiske indsigt med den socialhistoriske tradition.

\section{B. TERRY EAGLETON}

Terry Eagletons analyse af Brontë-s $\emptyset$ strenes - især af Charlotte Brontës - forfatterskab $\mathrm{i}$ bogen Myths of Power - A Marxist Study of the Brontës (1975), er et nyere eksempel på, hvordan socialhistorisk indsigt kan anvendes $\mathrm{i}$ litterære analyser. Som så mange andre engelske marxistisk orienterede litterater idag er Eagleton i sine teoretiske skrifter ${ }^{4}$ påvirket af både Williams og den franske strukturalisme. Men han er samtidig kritisk over for begge og optaget af at udvikle en marxistisk litteraturteori.

Den teoretiske side af hans forfatterskab vil næppe sige en velinformeret dansk læser meget - denne engelske udgave af fransk strukturalisme vil snarest forvirre. Derimod er hans konkrete litterære analyser bemærkelsesværdige ved deres socialhistoriske indsigt.

Brontë-s $\varnothing$ strenes forfatterskab blev i mange år opfattet som et resultat af en totalt isoleret tilværelse $i$ den fattige præstegård $i$ Yorkshire. Myten passer sammen med den borgerlige kunstnermyte om det ensomme individ, som alene skaber ud fra sin enestående genialitet. Myten om det ensomme liv på Yorkshires heder har ganske vist bund $\mathrm{i}$ virkeligheden, men samtidig er det langt fra hele sandheden.

Søstrene Brontës hjem i Haworth lå tæt ved et vigtigt centrum for uldindustrien i Yorkshire, og i deres levetid gennemgik det engelske samfund nogle af de voldsomste klassekampe nogensinde. Mens de var børn, forsvandt livsgrundlaget for tusinder af 
håndvævere, som fattigdommen siden drev fra landet ind til byerne. De levede kort sagt på nært hold af de begivenheder, som Marx $i$ »Kapitalen « omtaler som den frygteligste tragedie $i$ engelsk historie. Arbejderklassens reaktioner på industrialiseringen: maskinstorm, kampen mod den ny fattiglov, Chartismen (valgretsbevægelsen), agitationen mod kornlovene og for 10-timers arbejdsdagen - alt dette foregik i deres tid, og måske stærkest $\mathrm{i}$ det område, de boede i, West Riding. I selve Haworth, som langt fra var nogen idyllisk, førindustriel oase, var der adskillige kamgarnsfabrikker, og søstrene har givetvis oplevet den fattigdom og elendighed, som fulgte med industrialiseringen og vandringen fra land til by.

Det viser sig da også, at f.eks. Charlotte Brontë berører disse begivenheder mere eller mindre eksplicit i sine romaner. Men hvad der er vigtigere for Eagleton er, at det, han - med et Goldmann-udtryk - kalder værkernes kategoriale eller ideologiske struktur, springer ud af disse samfundsforhold, eller mere specifikt: ud af en konflikt mellem den gamle landadel og det nye industriborgerskab. Romanerne udfolder en kamp mellem to flertydige værdisæt, som kan føres tilbage til hhv. det industrielle borgerskab og landadelen (eller landaristokratiet). Det industrielle borgerskabs værdisæt omfatter: rationalitet, kulde, egennytte, energisk individualisme, radikal protest og oprør. Landadelen er forbundet med: fromhed, underkastelse, kultur, tradition og konservatisme. Romanens personligheds- og kærlighedskonflikter forløber da sinden $\mathrm{i}$ \& disse klassekonflikter. I slutningen af romanen \Shirley \&, eksempelvis, »forenes « de to klassefraktioner gennem en forening på det personlige plan mellem personer, som hver for sig personlighedsmæssigt repræsenterer værdier knyttet til de to klasser.

Eagletons analyse af disse historiske forhold bygger på en righoldig socialhistorisk litteratur om klasseforholdene i Yorkshireområdet og er derfor et udmærket eksempel på en sammensmeltning af litterær og socialhistorisk analyse. Socialhistorikerne fortæller nemlig, at Yorkshire nok var præget af konflikter mellem disse klassefraktioner, men ikke i nær så stor en udstrækning som 
i Sydengland. Til trods for konflikterne var der en forholdsvis kraftig tendens til sammensmeltning af de to fraktioners interesser, idet landadelen oprettede fabrikker på sine jorder eller lejede dem ud til industriherrerne - og industriborgerskabet opk $\varnothing$ bte godser for at styrke familiens anseelse.

Eagleton formår også at forklare, hvorfor disse klassekonflikter, og den delvise klasseudsoning, går så dybt ned i værkernes ideologiske struktur, som tilfældet er. Konflikterne mellem klasserne blev i søstrenes bevidsthed særligt forstærket af deres personlige situation. For det første var de placeret i en pinagtig mellemstilling $\mathrm{i}$ den sociale struktur. Som døtre af en præst uden avancementsmuligheder og formue førte de en stadig kamp for at opretholde en nogenlunde $\gg$ dannet levevis $\ll i$ et traditionelt sudannet « miljø. For det andet var de som kvinder anbragt i en socialt usikker position. Men de var også kvinder med en uddannelse og dermed i klemme i en umulig situation mellem kultur og $\phi$ konomi - mellem forestillingen om et bedre liv og forvisningen om at leve i et samfund, som kun kunne bruge dem som »højere tjenere, dvs. som guvernanter. Og de var isolerede, såvel socialt som geografisk, fra den kulturens verden, som de alligevel stod $i$ snæver forbindelse med gennem deres læsning af periodens vigtigste tidsskrifter, romaner, etc. Samtidig medførte denne isolation en f $\varnothing$ lelsesmæssig indadvendthed, enhver f $\varnothing$ lelse blev tvunget tilbage for at s $\varnothing$ ge tilfredsstillelse i sit eget udgangspunkt.

Charlotte Brontës visioner af, hvorledes hendes kvindelige romanpersoners problemer som isolerede guvernanter skulle $1 \varnothing$ ses, sammenfatter h $\varnothing$ jst uensartede forestillinger om en aristokratisk, velgørende paternalisme og en radikal vision af åndelig frihed. Sammenfletningen af disse vidtforskellige visioner bliver først i egentlig forstand forståelig, når man medreflekterer såvel de usikre interne klassefraktionsforhold i Yorkshire, som hendes egen usikre position som isoleret, uddannet, $\varnothing$ konomisk afhængig kvinde.

Erkendelsen i denne type analyse ligger i sin karakter ikke langt fra hjemlige analyser af forrige århundredes danske litteratur, som f.eks. Jørgen Holmgaards og Torben Grodals studier i 
»det moderne gennembruds « forfattere, men engelske, materialistiske litteraturkritikere som Terry Eagleton har som anført en bred, socialhistorisk tradition at trække på. Brontë-analysen er blevet omtalt så relativt udførligt ud fra det formål at vise, hvor nyttig denne tradition kan være. Analysen viser, hvor uomgængelig en socialhistorisk - og $\mathrm{i}$ dette tilfælde også regionalhistorisk tilgang - er for en nærmere forståelse af et forfatterskab.

\section{FORMIDLINGSPERSPEKTIVER}

Man kan nu spørge sig, om vi også kan få mere umiddelbar nytte af denne socialhistoriske og litteraturanalytiske tradition i gymnasie- og HF-undervisningen.

De her omtalte tekster kan næppe anvendes direkte $\mathrm{i}$ undervisningen, selv om f.eks. historikeren Hobsbawm findes repræsenteret $\mathrm{i}$ en engelskbog til brug for gymasium og HF. ${ }^{5}$ Men traditionen kan give os vigtige impulser; den viser, at det kan lade sig gøre at forene en bred, detaljeret beskrivelse af historiske livssituationer med et historisk-materialistisk udviklingsperspektiv, som vi f.eks. har set det hos E. P. Thompson.

Hermed er der skabt en historisk tilgang, som gennem kombinationen af det, man kunne kalde en ny form for $\gg$ bred sædeskildring * og begrebsligg $\varnothing$ relsen af væsenstrækkene ved den historiske udvikling, åbner for en på én gang oplevelsesmassig og begrebslig forholden sig til historien. I en pædagogisk sammenhæng er det overordentlig vigtigt at få begge disse sider af den historiske beskæftigelse med. Det er en almindelig erfaring, at det ofte er svært, om ikke umuligt, at motivere elever for historiske tekster. Måske skulle man også i denne forbindelse tage ved lære af den engelske socialhistoriker.

Som kan flere forskellige ting. John Burnett har udgivet en $\emptyset$ konomisk, statistisk orienteret $\gg$ History of the Cost of Living (1969), som til trods for sit spændende indhold næppe vil interessere andre end $\varnothing$ konomiske historikere. Men han har også udgivet en bog med arbejder-selvbiografier fra 1820 til 1920. I denne bog, »Useful Toil« (1974) fremlægger han således en del 
af det kildemateriale, som har dannet grundlag for hans værk om levevilkårene.

Det er læsning, som vil sige de fleste mere end alverdens tørre tal. På samme måde kan det være n $\varnothing$ dvendigt at befri »historien * i fagene dansk, historie, engelsk og tysk for blokerende abstraktioner ved at tage udgangspunkt $\mathrm{i}$ tekster og billeder, der går så tat som muligt på den oplevede historie.

\section{NOTER}

1 Dansk udgave: E. J. Hobsbawm: »Banditter«. Politisk Revy, 1978.

2 Perry Anderson: „Components of the National Culture«. I: »New Left Review» 50, juli-august 1968.

3 Raymond Williams: »Culture and Society«, s. 12.

4 Terry Eagleton: „Criticism and Ideology«, 1976.

5 Rigmor Bækholm, m.fl:: »Paris Today - London Tomorrow« (del af tværfagligt skolebogsprojekt om Pariserkommunen 1871). Gyldendal, 1975.

Af E. J. Hobsbawm findes oversat til norsk på Pax Forlag »Revolusjon i Europa 1789-1848« 1-2 og »Kapitalens epoke« 1-2. 


\section{Ib Bondebjerg}

\section{Historien, traditionen og arbejdererindringen ${ }^{1}$}

Om den borgerlige kultur og arbejderkulturen $i$ (litteratur)historien

\section{HISTORIEN, DAGLIGDAGEN OG ERINDRINGEN}

I den marxistiske historieopfattelse har der både traditionelt og $\mathrm{i}$ nyere tid - bl.a. fra »genopdagelsen « af marxismen i universitetsmiljøerne fra slutningen af 60 'erne - gjort sig tendenser galdende, der $\mathrm{i}$ deres fors $\emptyset \mathrm{g}$ på at overskride både den platte empirisme og den spekulative idealisme $\mathrm{i}$ den borgerlige historieopfattelse har forholdt sig til historien ved at søge at afdække stærkt abstrakte og objektive-logiske træk i den historiske udvikling. I deres mest ekstreme og rene form har disse tendenser ført til en a-historisk, abstrakt kategorisering af historien, men $i$ deres intention har disse tendenser ikke som helhed været meningsløse eller forkerte, men peger tværtimod på noget centralt i den materialistiske historieopfattelse: fors $\emptyset$ gene på at trænge igennem den umiddelbare, konkrete og mangfoldige historiske overflade og afdække en række væsenstræk i den $\varnothing$ konomiske, klassemæssige og bevidsthedsmæssige historie.

Men en sådan tilgang, der på den ene side er nødvendig i den samlede strukturering af lange historiske forl $\emptyset b$, hvis f.eks. periodiseringen skal ramme de steder, hvor de mere dybtgående ændringer optræder, bliver på den anden side for udvendig og utilstrækkelig, når man primært søger at bearbejde bevidstheds-, kultur- og litteraturformer, der måske nok kan ses i lyset af mere abstrakt udledte historiske væsenstræk, men som først og fremmest $\mathrm{i}$ allerhøjeste grad er komplekse fortolkninger og bearbejd- 
ninger af den subjektivt erfarede, historiske dagligdag. Det er ikke mindst forholdet mellem denne mere overordnede, objektive historiske udvikling og den subjektivt erfarede dagligdag, der må stå $i$ centrum i en materialistisk litteraturhistorie, og som netop kan aflæses i de litterære tekster som historien afsætter. Fiktive og erindrende tekster giver som erfaringsberetninger udsagn om kompleksiteten, uensartetheden, usamtidigheden, modsigelserne i den konkrete historiske virkelighed, og muligvis endda om de faktiske eller $\emptyset$ nskede alternativer - de muligheder og potentialer som af den ene eller den anden grund ikke blev fuldt udfoldet eller ikke satte sig dominerende igennem $i$ historien. Det er imidlertid ikke meningen her at fortsætte $\mathrm{i}$ et historiefilosofisk spor eller at fremkomme med generelle metodiske bemærkninger om historien og dagligdagen i almindelighed, det der skal fokuseres på er de undertryktes historie og deres erindring om og fortolkning af deres egen historie, således som den kommer til udtryk hos arbejderklassen i det borgerlige samfund.

Når man skal skrive en litteraturhistorie på materialistisk grundlag, så rejser det ikke bare det grundlæggende problem at få den historiske analyse til at bevæge sig ned fra en generel udviklingsskematik og få den til at opsuge og strukturere den konkrete socialhistoriske erfaringsverden, men det rejser naturligvis også et omfangs- og stofproblem i forhold til den traditionelle, overleverede litteraturhistorie, der $\mathbf{i}$ sidste instans hænger sammen med et andet syn på historien og litteraturen. Selve den klassemæssige og socialhistoriske vinkel på historien og litteraturen flytter vægten fra $\gg$ keglens top «, den litterære kànon til »keglens brede fod «, de udgrænsede traditioner. Udtrykket »keglens top $*$ og dens $\gg$ brede fod «, der er et billedligt udtryk hentet fra Troels Lunds forord til Dagligt liv i Norden, hvor han argumenterer for at flytte vægten fra historien om de store strukturer, personer og begivenheder og ned $\mathrm{i} \gg$ historiens understrøm $\ll$, det mere træge, daglige liv $\mathrm{i}$ arbejde, familie og fritid osv., kan for så vidt overføres polemisk på den traditionelle litteraturhistorie (og historieskrivning) $i$ to betydninger: ${ }^{2}$ på den ene side angiver »keglens top « den fokusering, der $\mathrm{i}$ den traditionelle litteraturhistorie er på rækken af centrale 